
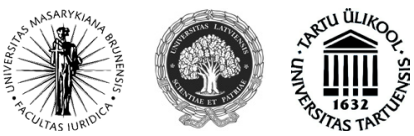

ISSN 1392-6195 (print) ISSN 2029-2058 (online) JURISPRUDENCIJA JURISPRUDENCE 2014, 21(1), p. 25-43.

\title{
IŠ LIETUVOS TEISMŲ ISTORIJOS: APELIACINIAI RŪMAI (1933-1944)
}

\author{
Mindaugas Maksimaitis \\ Mykolo Romerio universiteto Teisès fakulteto \\ Teisès filosofijos ir istorijos katedra \\ Ateities g 20, LT-08303 Vilnius, Lietuva \\ Telefonas (+370 5) 2714697 \\ Elektroninis paštas mindaugasmaksimaitis@mruni.eu \\ Pateikta $2014 \mathrm{~m}$. vasario 6 d., parengta spausdinti $2014 \mathrm{~m}$. kovo $13 \mathrm{~d}$. \\ doi:10.13165/JUR-14-21-1-02
}

\section{İžanga}

Skaitytojų dèmesiui siūlomas straipsnis ${ }^{1}$ tęsia mūsų publikaciją Lietuvos bendrosios kompetencijos teismų sistemos raidos tema, skirtą 1918-1933 metų laikotarpiui, apibūdintam teismų santvarkos pagrindų formavimosi metais². Šiuokart aptariama 1933 m. rugsèjo 15 d. ịsteigta nauja tos sistemos grandis - Apeliaciniai rūmai. Straipsnyje siekiama atskleisti šios teisminès institucijos įsteigimo tikslus ir eigą, jos organizacijos ir veiklos pagrindus bei reikšmę.

Literatūroje Apeliacinių rūmų istorija nušviesta ypač šykščiai: jauniausia Lietuvos teismų sistemos grandis, kurios įsteigimu anuomet siekta sudaryti sąlygas visiškai

1 Straipsnis parengtas pranešimo, autoriaus skaityto iškilmingame susirinkime Apeliacinio teismo aštuoniasdešimties metų sukakčiai pažymèti, vykusiame 2013 m. gruodžio 16 d., pagrindu.

2 Maksimaitis, M. Teismu santvarkos pagrindu formavimasis Lietuvoje (1918-1933). Jurisprudencija. 2013, 20 (2).

Jurisprudencija/Jurisprudence

(C) Mykolo Romerio universitetas, 2014

(C) Mykolas Romeris University, 2014
ISSN 1392-6195 (print), ISSN 2029-2058 (online) http://www.mruni.eu/lt/mokslo_darbai/jurisprudencija/ http://www.mruni.eu/en/mokslo_darbai/jurisprudencija/ 
įtvirtinti kasaciją Lietuvos teismų sistemoje, suvienodinti instancines proceso šalių galimybes ir ị atskiras teismo institucijas išskirti apeliacinị ir kasacinị procesus - pašalinti trūkumus, kuriuos turèjo teismų sistema, paskubomis 1918-1919 metais organizuota atkuriant Lietuvos valstybingumą, esamuose moksliniuose tyrinéjimuose paminima tik prabègomis.

Nekartojant minètame mūsų straipsnyje publikuotos esamos literatūros Lietuvos teismų sistemos raidos tematika apžvalgos, šiame straipsnyje nagrinejjamo laikotarpio Lietuvos teismų santvarkos klausimu ją reiketų papildyti 40 puslapių apimties specialiu dvikalbiu jubiliejiniu leidiniu³, pasirodžiusiu 2003 metais Apeliacinio teismo septyniasdešimtmečio proga ir trumpai apibūdinančiu šios teisminès institucijos istorinị kelią, taip pat neseniai apginta sovietmečio Lietuvos teismams skirta D. Sagatienès daktaro disertacija, kurioje, aptariant Lietuvos Respublikos teismų naikinimą pirmosios sovietinès okupacijos metais, tam tikra vieta skiriama Apeliacinių rūmų ir jų teisejjų likimui ${ }^{4}$. Be to, A. Vilbiko knygoje ${ }^{5}$ paskelbta informacija apie personalinę Apeliacinių rūmų sudètị ir jos kaitą konkrečiais istoriniais laikotarpiais.

\section{Teisminès kasacijos problema pirmaisiais Lietuvos nepriklausomybės metais ir jos sprendimo paieškos}

Siekiant patyrinèti svarbiausios apeliacinès instancijos tarpukario Lietuvos teismų sistemoje - Apeliacinių rūmų - atsiradimą, neišvengiamai susiduriama su paradoksalia, atrodytų, situacija, nes tą atsiradimą lèmẻ ne buvę apeliacijos trūkumai, o suvoktas nesamos kasacinès instancijos reikalingumas.

Padètis atsikuriančioje, Pirmajam pasauliniam karui baigiantis, Lietuvos valstybejje buvo atvèrusi itin plačią erdvę teismų veiklai: karui išblaškius žmones, daugeliui jų palikus savo užgyventą gerą ir pabègèliais išsidanginus ị Rusiją, patekus $\mathfrak{i}$ kariuomenę arba ị belaisvių stovyklas Vokietijoje, pasilikusieji neretai buvo užvaldę svetimą nekilnojamą ir kilnojamą turtą, jau nekalbant apie tai, jog karo ir nepriteklių metais neregètai išaugo nusikalstamumas, o teismai okupacijos sąlygomis menkai su tuo tekovojo ${ }^{6}$.

Bendrosios kompetencijos teismų sistemą Lietuvoje ịteisinęs Valstybès Tarybos 1918 m. lapkričio 28 d. priimtas įstatymas - Laikinasis Lietuvos teismų ir jų darbo sutvarkymas ${ }^{7}$, ivedè kai kurias naujoves laikinai paliktuose galioti atitinkamuose iki-

3 Lietuvos apeliacinis teismas. The Court of Appeal of Lithuania [be v. ir d.].

4 Sagatiené, D. Sovietiniai bendrosios kompetencijos teismai Lietuvoje 1940-1941 ir 1944-1953 metais. Daktaro disertacija. Socialiniai mokslai, teisè. Vilnius: Mykolo Romerio universitetas, 2013, p. 47-49.

5 Vilbikas, A. Teismai ir teiséjai Lietuvoje (1918-2008). Šiauliai, 2009, p. 109-110 ir kt.

6 Mačys, V. Teisingumo ministerijos 1921 metų darbuotès apžvalga. Teisè. 1922, 2:23.

7 Laikinasis Lietuvos teismų ir jų darbo sutvarkymas. Laikinosios Vyriausybès žinios. 1919, Nr. 2-3/26. 
kariniuose Rusijos įstatymuose, pirmiausia 1864 metų Teismo statute, reglamentavusiame teismo ịstaigu sąrangą (Rusijos imperijos įstatymų sąvado XVI t.): atsisakyta luominių teismų bei sustabdytas visuomenès atstovų dalyvavimas teismo procese ${ }^{8}$, panaikinti prieškariniai valsčiaus ir miesto teismai, jų nebaigtos bylos perduotos taikos teisejjams, likviduotas skirtumas tarp bendrosios ir taikos teismų teisenos. Pati teismų sistema, ano meto apibūdinimu, buvo „supaprastinta iki kraštutinumo“, sukonstruota pagal vokiečių okupuotoje teritorijoje veikusios sistemos (Friedensgerichte-Bezirksgerichte-Obergericht) pavyzdį ${ }^{9}$ Pirmujjų dviejų pakopų teismai - taikos teisejjai ir apygardos teismai - priklausomai nuo jų sprendžiamų civilinių bylų ieškinio kainos ar nusikaltimų baudžiamosiose bylose sunkumo, paprastai buvo pirmosios instancijos teismais, jiems, be to, pavestos apeliacijos funkcijos visoms pirmųjų išnagrinètoms byloms; aukščiausiaja teismo instancija Lietuvoje paskelbtas Vyriausiasis Tribunolas, kuriam apeliacine tvarka buvo galima skųsti apygardos teismų nutarimus visose bylose, jų išnagrinètose pirmosios instancijos tvarka. Ši sistema buvo vertinama kaip tinkama besikuriančiai valstybei: „Ar gali būti paprasčiau ir geriau!“10.

Apeliaciniai bet kurios grandies teismų sprendimai tuomet laikyti galutiniais, kasacijos Laikinasis teismų sutvarkymo įstatymas nenumate. Oficialiame laikinojo teismų sutvarkymo ịstatymo paaiškinime ${ }^{11}$ samprotauta, kad pagrịstam bylos sprendimui užtenka pirmosios ir apeliacinès teismo instancijų pastangų, tuo tarpu kasaciné instancija teisingą bylos sprendimą galinti tik suardyti; šios instancijos nauda apskritai esanti abejotina ir ginčijama net ir kasaciją praktikuojančiose šalyse. Reikštas įsitikinimas, jog vienodo teisès aiškinimo uždavinị, paprastai sprendžiamą kasacinio teismo, Lietuvoje sugebėsiantis išspręsti Vyriausiasis Tribunolas, veikdamas kaip bendra visai Lietuvai apeliacinè instancija. Be viso to, kasacijos instancijos kuriamoje teismų sistemoje nenumatymas aiškintas dar ir kaip laikinas - „iki gyvenimas parodys šios reikalingumą".

Tiesa, ne visi išmanantys reikalą buvo linkę sutikti su šia oficialia nuomone. Beveik tuo pat metu pradejjęs mokslininko karjerą M. Römeris kasacinị teismą viešai apibūdino pasaulineje praktikoje jau pasiteisinusia ir vienintele įmanoma bendrosios kompetencijos teismų sprendimų teisètumo kontrolès priemone; teismų sprendimai, pasak jo, turintys remtis ịstatymais, bet dèl galimų teisejo įstatymo interpretavimo klaidų ar kitų priežasčių, o kartais netgi dèl piktos valios jo sprendimas galintis neatitikti įstatymo arba net įstatymui prieštarauti, todèl žemesnio teismo priimamų aktų teisètumui kontroliuoti kasacinis teismas esantis būtinas ${ }^{12}$.

8 Byla, J. Lietuvos teismo dvidešimtmečio sukaktis. Teisè. 1938, 44: 361-362; Toliušis, Z. Lietuvos teismy sutvarkymas. Antroji laida. Kaunas, 1926, p. 3.

9 Lietuvos teismas 1918-1928. Red. A. Kriščiukaitis. Kaunas: Teisingumo ministerija, 1930, p. 202.

10 Skipitis, R. Petras Leonas - Lietuvos teisingumo kūrèjas. Teisininkų žinios. 1965, 27/28: 20.

11 Paaiškinimas įstatymui „Laikinasis Lietuvos teismų ir jų darbo sutvarkymas“. Laikinosios Vyriausybés žinios. 1919, Nr. 2-3/27.

12 Römeris, M. Konstitucinès ir teismo teisès pasieniuose. Kaunas: Vytauto Didžiojo universiteto Teisių fakultetas, 1931, p. 19, 50. 
Prie kasacijos problemos sprendimo Lietuvoje realiai priartèta jau 1921 metais, Steigiamajam Seimui priemus Laikinojo teismų sutvarkymo ịstatymo papildymą $^{13}$, pavedusị Vyriausiajam Tribunolui nagrinèti kasacinius skundus dèl apygardos teismų sprendimų ir nutarimų jų apeliacine tvarka išnagrinėtose reikšmingesnèse baudžiamosiose ir civilinèse bylose, įstatyme apibrèžtose atitinkamai teismo skirtos bausmès ar ieškinio kainos didumu.

Ivesta naujovè neabejotinai praplètė procesines šalių galimybes, bet sykiu ji išbalansavo veikusią teismų sistemą. Ji reiškẻ, pirmiausia, kad tame pačiame teisme Vyriausiajame Tribunole - buvo sutelktos ne tik apeliacinès, bet ir kasacinès teismo funkcijos, neskaitant dar ir baudžiamųjų bylų, iškeltų Respublikos prezidentui, ministrui pirmininkui ar kuriam kitam ministrui už tarnybinius nusikaltimus ar valstybės išdavimą, kurias 1922 metų Lietuvos Valstybės Konstitucija jam, kaip aukščiausiajam teismui, pavedè nagrinèti pirmosios (ir galutinès) instancijos tvarka; antra, kasuoti pagal ši įstatymo pakeitimą tebuvo galima tik tam tikrą dalị bylų, būtent tik dèl taikos teisèjo priimtų sprendimų, apeliacine tvarka jau išnagrinètų apygardos teismuose, t. y. faktiškai tik paprastesnèse, dèl lengvesnių nusikaltimų ir pigesnių ieškinių bylose, ịstatymo pavestose taikos teisejjų kompetencijai, tuo tarpu apygardos teismų sprendimams, priimtiems pirmosios instancijos tvarka, Vyriausiasis Tribunolas ir toliau liko vien tik apeliacine instancija, kasacija šiems sprendimams ir toliau nebuvo taikoma.

Minètu įstatymu įvesta kasacija dèl šios priežasties reikalo neišsprendè, net, galima pasakyti, jos taikymą elementaraus teisingumo požiūriu padarė nepakenčiamą ir nepateisinamą, nes daliai bylų (pradètoms taikos teisme), buvo leistos trys, o pirmosios instancijos tvarka nagrinètoms apygardos teisme - tik dvi teismo instancijos, kasacijos galimybės žymi bylininkų dalis apskritai negavo. Juolab kad būtent apygardos teismuose pirmąja instancija buvo nagrinèjamos svarbesnès, dèl sunkesnių nusikaltimų ir dèl brangesnių ieškinių, ir sudètingesnès bylos, tad kasacijos galimybė čia neabejotinai buvo net aktualesnè nei bylose, pirmąja instancija nagrinètose taikos teisèjų.

Kasacinio teismo Lietuvoje problemą savo veikaluose, parašytuose teisinès valstybės problematika, toliau nekart kèlè M. Römeris. Atsižvelgdamas i tai, kad kasacinio teismo funkcija Lietuvoje esanti pavesta teismo institucijai, atliekančiai taip pat ir apeliacinio teismo funkcijas, dar svarbiau - kad kasacinis procesas apimantis ne visus baudžiamųjų ir civilinių teismų darbo rezultatus, M. Römeris teigé, jog mūsų valstybè kasacinio teismo tikrąja prasme neturinti, atsiradusi tiktai jo užuomazga; jau vien dèl to, kad nebuvęs numatytas kasacinis teismas, kurị jis laikè būtina autoritetinga teismų sistemos viršūne, ịstatymo nustatytoji teismo konstrukcija Lietuvoje likusi neužbaigta ${ }^{14}$.

13 Laikinojo Lietuvos teismų ir jų darbo sutvarkymo, civilinio ir baudžiamojo proceso i̇statymų pakeitimas ir papildymas. Vyriausybés žinios. 1921, Nr. 68/607.

14 Römeris, M. Administracinis teismas. Kaunas: Lietuvos universiteta, Teisių fakultetas, 1928, p. VII; Römeris, M. Teisinès valstybės organizacija. Lietuvos universitetas 1927-1928 mokslo metais (1927.IX.15-1928.II.16). Kaunas: Lietuvos universitetas, 1928, p. 30. 
Nepaisant kritiško teisinės visuomenès (taip pat ir pačių 1918 metų Laikinojo teismų sutvarkymo įstatymo rengèjų) požiūrio ị kai kurias šio akto nuostatas ${ }^{15}$, visas įstatymas pasirodè esąs ganètinai gyvybingas, nè viena politiné grupé Seime jo peržiūrèjimo klausimo nekèlè, tenkintasi vos keletu neesminių jo pakeitimų ${ }^{16}$. Šiek tiek daugiau buvo dirbama tik Teisingumo ministerijos kabinetuose, ypač pirmoje trečiojo dešimtmečio pusejje funkcionuojant krikščioniškajai Vyriausybei.

Didžiausiu šio laikotarpiu teisinès kūrybos darbu, vykdant šios Vyriausybès ir ypač jos teisingumo ministro A. Tumèno užsibrèžtą ir savo veiklos pradžioje Seimui pateiktą programą ${ }^{17}$, laikytinas 1924 metais parengtas išsamus naujo Teismų sutvarkymo îstatymo projektas ${ }^{18}$. Pagrindinès jame turejo būti normos, numatančios atnaujinti ir, visiškai įteisinant kasaciją, papildyti bendrosios kompetencijos teismų sistemą: dabar ji turejjo susidèti jau ne tik iš taikos teisejjus pakeisiančių nuovadų teisejjų, taip pat apygardų teismų ir daugiausia iki tol užsiiminejjusio apeliaciniais skundais Vyriausiojo Tribunolo - svarbiausiu esamos teismų sistemos pakeitimu ịstatymo projekto kūrèjai laikè jos papildymą nauja, be to, dar ir aukščiausia grandimi sistemoje - specialiu kasacijos ir revizijos teismu, ịvardintu Senatu. Kartu ketinta suvienodinti proceso šalių padètį, suteikiant joms teisę, esant reikalui, pasinaudoti apeliacinio ir kasacinio teismo instancijų teikiamomis galimybėmis; be to, pasak projekto rengejjų, bylų sprendimo tvarka apeliaciniame ir kasaciniame teismuose esanti ganėtinai skirtinga, todèl jas nagrinèti tame pačiame teisme nesą tikslinga. Pagaliau - buvo pripažinta, jog šešeri nepriklausomos Lietuvos teismų veiklos metai ịtikinę, jog sunku esą teismų veiklą tinkamai sutvarkyti be grynai kasacinio teismo ${ }^{19}$.

Parengtas Teismų sutvarkymo įstatymo projektas, gavęs Teisingumo ministro tarybos pritarimą ${ }^{20}$, suspejjo pasiekti Seimą, bet, A. Tumėnui iš teisingumo ministro posto pasitraukus, Vyriausybe 1925 metų projektą iš ten atsièmé ir èmési ji dar tobulinti. Tik 1928 metų rudenị îsteigus Valstybès Tarybą, kuriai, tarp kitų funkcijų, įstatymu specialiai pavesta užsiimti įstatymų projektų rengimu, teismų reformos projektas pateko ị jos rankas ${ }^{21}$. Po intensyvių dar keleto metų pareikalavusių Valstybės Taryboje specialiai sudarytos komisijos ir visos vyriausybės bendrų pastangų užbaigtas Teis-

15 Lietuvos Valstybés Tarybos protokolai 1917-1918. Sudare A. Eidintas ir R. Lopata. Vilnius: Mokslas, 1991, p. 399-401, 406-410.

16 Laikinojo Lietuvos teismų ir jų darbo sutvarkymo ịstatymo pakeitimas. Vyriausybès žinios. 1924, Nr. 160-1140; 1926, Nr. 238-1543.

17 Paaiškinamasis raštas prie Teismų sutvarkymo įstatymo projekto. Lietuvos centrinis valstybès archyvas (toliau-LCVA). F. 1556, ap. 3, b. 16, lap. 18.

18 Teismų sutvarkymo įstatymas. Projektas. LCVA. F. 1556, ap. 3, b. 16, lap. 1-17.

19 Supra note 17.

20 Baudžiamojo proceso įstatymas (bendrieji desniai ir pirmoji knyga). „Teisès“ priedas A. Kriščiukaičio suredaguotas. Kaunas, 1924, p. 186.

21 Ministrų Kabineto 19280807 pos. protokolas. LCVA. F. 923, ap. 1, b. 556, lap. 93. 
mų santvarkos įstatymas ${ }^{22}$, pagal tuomet galiojusią tvarką gavęs Ministrų Kabineto pritarimą ir $1933 \mathrm{~m}$. liepos $11 \mathrm{~d}$. paskelbtas Respublikos Prezidento, tapo bendrosios kompetencijos teismų sistemos reformos, užpildžiusios jau Teismų sutvarkymo įstatymo projekte pradètas konstruoti keturias jos grandis ir, pagaliau, visiškai ịteisinusios kasacinę instanciją, teisiniu pagrindu.

\section{Apeliacinių rūmų vieta Lietuvos teismų sistemoje}

Žemutine naujosios teismų sistemos grandimi tapo taikos teisejjus pakeitę apylinkių teismai. Šių teismų kompetencija, išskyrus tai, kad jiems dabar, be paprastesnių baudžiamųjų bylų, buvo pavestos visos civilinės bylos, priminė anksčiau buvusių taikos teisejjų kompetencija. Liko išsaugoti taip pat ir apygardos teismai - pagrindinis teismas baudžiamosioms byloms spręsti pirmosios instancijos tvarka, taip pat apeliacinè instancija apylinkių teismų nagrinètoms byloms.

Bene svarbiausia naujovė naujajame įstatyme - siekiant suvienodinti instancines proceso šalių galimybes bei ị atskiras teismo institucijas išskirti apeliacinị ir šịkart iki galo ịteisinamą kasacinị procesus, ị teismų sistemą papildomai ịvesta nauja grandis, tiesa, ne i aukščiausią, kaip isstatymo projekto rengimo pradžioje buvo manoma, o i trečią hierarchijos pakopą, ir skirta ne kasacijai, o apeliacijai - bendras visai respublikai teismas, šịkart ir pavadintas Apeliaciniais rūmais. Aukščiausiąja teismų sistemos grandimi ir toliau paliktas Vyriausiasis Tribunolas, bet netekęs apeliacijos funkcijų ir nuo šiol paverstas bendra visai valstybei kasacine instancija. Taigi, palyginti su pradiniu 1924 metų projektu, naujoji teismų sistemos grandis, pirma, sudarė jau ne sistemos viršūnę, o pateko, galima sakyti, ị jos vidurịi; antra - ji buvo sukurta ne trūkstamai kasacijai, o, naujai perskirsčius teismines funkcijas sistemos viduje, kaip apeliacinè instancija.

Papildoma teismų sistemos grandis, ịkūnyta Apeliaciniuose rūmuose, teisinès visuomenès buvo priimta supratingai, kaip pribrendęs ir didesnių abejonių nekeliantis dalykas. Kai kam teužkliuvo jos pavadinimas: samprotauta, nekalbant apie paties „apeliacijos“ termino vartojimą („lietuviai apeliaciją vadina atšaukimu“), jog naujos teismo grandies įvardijimas „apeliaciniais rūmais“, tuo nusakant instancinę jo paskirtị sistemoje, pirmiausia, nesiderinantis su žemesniųjų - apylinkès ir apygardos - teismų pavadinimais, akcentuojančiais teritorinị jų paskirties momentą; negana to, teismo institucijai netinkantis „rūmų“, pagal žodžio prasmę reiškiančio didelị puošnų namą, pavadinimas - ji neva turètų vadintis tiesiog apeliaciniu teismu, lygiai kaip ir Vyriausiasis Tribunolas - kasaciniu teismu ${ }^{23}$.

Apeliacinių rūmų ịsteigimo diena laikoma 1933 m. rugsèjo 15 d., ịsigaliojus naujajam Teismų santvarkos ịstatymui ir jam èmus veikti ${ }^{24}$. 
Likus mėnesiui iki numatyto įstatymo įsigaliojimo, buvo paskelbtas Teisingumo ministerijos etatų pakeitimas ${ }^{25}$, naujiesiems Apeliaciniams rūmams numatęs pirmininko ir penkių teisèjų (neskaitant trylikos kitų teismo tarnautojų) etatus. Teisiamąji Apeliacinių rūmų posėdị turèjo sudaryti trys teisẻjai, todèl suvokiant, kad nustatytas teisejjų skaičius gali neužtikrinti sklandaus teismo darbo, Teismų santvarkos ịstatymas (37 str.) leido, teisiamojo posėdžio sudéčiai neužtenkant teisejjo, Apeliacinių rūmų pirmininkui ją papildyti kuriuo nors apygardos teismo teisejju. Visi Apeliacinių rūmų (Vyriausiojo Tribunolo, apygardos teismų) teisèjai sudarè jų visuotinį susirinkimą, kuriam pavesta kandidatų teisejjų vietoms užimti parinkimas, ịvairių pranešimų išklausymas ${ }^{26}$.

Vèliau, tiesa, Apeliacinių rūmų teisèjų etatų skaičius buvo didinamas ${ }^{27}$ ir sovietinès okupacijos išvakarèse juose, įskaitant ir teismo vadovybę, dirbo dešimt teisèjų. Pagal teisejjų skaičių tai buvo vienas neskaitlingiausių aukštesnųjų Lietuvos teismų: Vyriausiajame Tribunole sovietinès okupacijos išvakarèse dirbo penkiolika teisẻjų, Kauno apygardos teisme - dvidešimt vienas, Šiaulių ir Panevėžio apygardos teismuose - po dešimt ir tik Marijampolès - aštuoni ${ }^{28}$ bei tuo metu dar beatsikuriančiame Vilniaus apygardos teisme - šeši ${ }^{29}$ teisèjai.

Per dešimtị metų vien Lietuvos universiteto Teisių fakulteto veiklos dèka aukštuosius teisès mokslus Lietuvoje buvo spejję baigti per pusę tūkstančio specialistų ${ }^{30}$, todèl 1933 metų Teismų santvarkos įstatymas jau turèjo realų pagrindą teismų darbuotojams kelti pakankamai aukštus kvalifikacinius reikalavimus. Be bendro pobūdžio visiems teisejjams reikalavimų - 25 metų amžiaus ir aukštojo išsilavinimo, - pretendentams ị Apeliacinių rūmų teisèjus ịstatymas numatè reikalavimą turèti bent trejų metų ne žemesnių pareigų kaip apygardos teismo teisejo stažą, o ì pirmininko pareigas galejo pretenduoti turintys šių pareigų bent devynerių metų stažą.

Išsaugant teisèjų skyrimo principą, 1933 metais Teismų santvarkos ịstatymu ši funkcija, teisingumo ministro teikimu, pavesta Respublikos Prezidentui. „Nauja buvo tai, kad tam tikrą galimybę skyrimus ịtakoti gavo patys teismai: kandidatų i Apeliacinių Rūmų teisejjus sąrašą pavesta sudarinèti visuotiniam šio teismo teisèjų susirinkimui; iš pasiūlytų kandidatų (arba ir ne iš jų) savo nuožiūra parinkęs pretendentus, teisingumo ministras galèjo su atitinkamomis charakteristikomis juos teikti prezidentui (127-129 str.).“

Teisingumo ministerijos etatų pakeitimas. Vyriausybès žinios. 1933, Nr. 422-2917.

Baltūsis, S. Lietuvos teismai. Sèja. 1974, 1/2: 26.

Supra note 25, Vyriausybès žinios. 1934, Nr. 437-3046; 1939, Nr. 631-4525.

Baltūsis, S., supra note 26, p. 25.

Respublikos prezidento aktai. Vyriausybès žinios. 1939, Nr. 675-4992, 4994, 4995, Nr. 6795033; Oficialinè dalis. Teisé. 1940, 50: 2.

Vilniaus universiteto istorija 1803-1940. Vilnius: Mokslas, 1977, p. 248. 
Apeliacinių rūmų pirmininku visą aptariamą laikotarpị buvo J. Gudauskis (išskyrus keturių mėnesių laikotarpi 1938-1939 metais jam tapus teisingumo ministru) $)^{31}$, prieš tai nuo 1923 metų dirbęs taikos teisejju Tauragèje, o nuo 1927 metų Panevėžio apygardos teismo teiseju, vèliau - pirmininku. Pirmininko pavaduotoju, ịstatyme ivvardytu antrininku, ịsteigus 1939 metais šị etatą ${ }^{32}$, paskirtas teisejjas S. Dorošukas.

Sovietinès okupacijos išvakarèse, be J. Gudauskio ir S. Dorošuko, Apeliaciniuose rūmuose teisèjais dirbo A. Augustauskas-Brèdikis, E. Balbachas, P. Budrevičius, K. Kazlauskas, P. Niuneva, M. Rašinskas, S. Sasnauskas ir V. Šarka. Be paminètųjų, per septynerius Apeliacinių rūmų funkcionavimo metus teisèjais ilgesnị ar trumpesnị laiką čia buvo dirbę dar S. Baltūsis, S. Leonas, M. Mataitis, A. Ronkus ir S. Žilinskas ${ }^{33}$.

Prie Apeliacinių rūmų tuo metu veikè prokuroras, keturi jo padejejjai ir trys ypatingieji tardytojai.

Apeliacinių rūmų kompetencijai nusakyti buvo skirti trys Teismų santvarkos isstatymo straipsniai. Pirmiausia įstatymo 18 straipsnis skelbẻ, jog Apeliaciniai rūmai yra „apeliacinè instancija byloms, kurias spendžia apygardų teismai pirmąja instancija“. Toliau įstatymas nustate, jog Apeliaciniai rūmai yra ir pirmosios instancijos teismas: šia tvarka jam pavestos baudžiamosios bylos dẻl nusikalstamų darbų, padarytų „prieš valstybės saugumą“" (19 str.), kiek jos nepriklausẻ karinių teismų kompetencijai, kitaip tariant - kiek jose nusikalstamos veikos nebuvo kvalifikuojamos pagal Ypatingus valstybès apsaugos įstatus. Pagaliau, Apeliaciniai rūmai buvo teismas byloms, „kurias jiems paveda kiti įstatymai“ (20 str.).

Turimi statistiniai duomenys apie Apeliaciniuose rūmuose užbaigtas bylas atskirais metais (1933 ir 1935-1939) pateikiami lentelejeje ${ }^{34}$.

Iš lentelès duomenų matyti:

1. Pagrindinę Apeliaciniuose rūmuose baigtų bylų dalį, neskaitant „kitų“, sudarè bylos, nagrinètos antrosios instancijos (apeliacine) tvarka, pirmosios instancijos tvarka prieš tai išnagrinètos apygardos teismuose: turimais statistiniais duomenimis, jų per nurodytą laiką būta 5403 (pirmosios instancijos tvarka per tą patị laikotarpi Apeliaciniuose rūmuose išspręsta 340 bylų, arba beveik šešiolika kartų mažiau).

31 Oficialinè dalis. Teisè. 1933, 24: 48.

32 Teismų santvarkos ịstatymo pakeitimas. Vyriausybès žinios. 1939, Nr. 631-4531.

33 Baltūsis, S., supra note 26, p. 30-31.

34 Lentelè sudaryta remiantis duomenimis, publikuotais: Bylų eiga Apeliaciniuose rūmuose 1933 metais. Teisè. 1934, 25: 95; Bylų eiga Apeliaciniuose rūmuose 1935 metais. Teisè. 1936, 33: 113; Bylų eiga Apeliaciniuose rūmuose 1936 metais. Teisè. 1937, 37: 146; Bylų eiga Apeliaciniuose rūmuose 1937 metais. Teisé. 1938, 41: 140; Bylų eiga Apeliaciniuose rūmuose 1938 metais. Teisè. 1939, 45: 110; Bylų eiga Apeliaciniuose rūmuose 1939 metais. Teisé. 1940, 50: 75. 
Duomenys apie Apeliaciniuose rūmuose užbaigtas bylas

\begin{tabular}{|c|c|c|c|c|c|c|c|c|c|c|}
\hline \multirow{3}{*}{ Metai } & \multirow{2}{*}{\multicolumn{3}{|c|}{$\begin{array}{l}\text { Antroji instancija } \\
\text { (İstatymo } 18 \text { str.) }\end{array}$}} & \multirow{2}{*}{\multicolumn{3}{|c|}{$\frac{\text { Pirmoji instancija }}{\text { (İstatymo } 19 \text { str.) }}$}} & \multirow{2}{*}{\multicolumn{3}{|c|}{$\begin{array}{c}\text { Kitos bylos } \\
\text { (Itstatymo } 20 \text { str.) }\end{array}$}} & \multirow{3}{*}{ Iš viso } \\
\hline & & & & & & & & & & \\
\hline & $\begin{array}{c}\text { Civili- } \\
\text { nès }\end{array}$ & $\begin{array}{c}\text { Baudžia- } \\
\text { mosios }\end{array}$ & Iš viso & $\begin{array}{l}\text { Civili- } \\
\text { nès }\end{array}$ & $\begin{array}{c}\text { Baudžia- } \\
\text { mosios }\end{array}$ & Iš viso & $\begin{array}{l}\text { Civili- } \\
\text { ninès }\end{array}$ & $\begin{array}{c}\text { Baudžia- } \\
\text { mosios }\end{array}$ & Iš viso & \\
\hline 1933 & 45 & 169 & 214 & - & - & - & 22 & 462 & 484 & 698 \\
\hline 1935 & 187 & 1112 & 1299 & - & 68 & 68 & 76 & 747 & 823 & 2190 \\
\hline 1936 & 95 & 922 & 1017 & - & 104 & 104 & 549 & 618 & 1167 & 2288 \\
\hline 1937 & 52 & 803 & 855 & - & 78 & 78 & 183 & 668 & 851 & 1784 \\
\hline 1938 & 32 & 818 & 850 & - & 43 & 43 & 58 & 547 & 605 & 1498 \\
\hline 1939 & 61 & 1107 & 1168 & - & 47 & 47 & 20 & 496 & 516 & 1731 \\
\hline
\end{tabular}

2. Lentelèje pateikiami duomenys rodo, kad pagrindinę dalị bylų, antrosios instancijos tvarka išnagrinètų Apeliaciniuose rūmuose, sudarẻ baudžiamosios bylos 4931, arba 91 procentą visų čia apeliacine tvarka išnagrinètų bylų. Civilinės bylos tesudare nežymią likusiąją Apeliacinių rūmų antrosios instancijos tvarka išnagrinètų bylų dalį. Tai laikina ir, kaip rodo lentelè duomenys, mažéjanti šio teismo krūvio dalis: pagal iki 1933 metų galiojusią tvarką apygardos teismai pirmąja instancija buvo ne tik baudžiamosioms, bet ir brangesnėms civilinėms byloms, kuriose sprendimai apeliacine tvarka tuomet galèjo būti skundžiami Vyriausiajam Tribunolui; įsigaliojęs Teismų santvarkos įstatymas, kuris visas civilines bylas perdave apylinkès teismams, apygardos teismus ịpareigojo jų pradetas ir neužbaigtas pirmosios instancijos bylas, tarp jų civilines, užbaigti, bet apeliacine instancija joms, pagal Teismų santvarkos įstatymo 413 ir 414 straipsnius, jau tapo Apeliaciniai rūmai.

3. Teismų santvarkos įstatymo 16 straipsnyje įvardijant pirmosios instancijos tvarka apygardos teismuose išnagrinètąsias bylas, apeliacine tvarka perduodamas nagrinèti Apeliaciniams rūmams, konkrečiai omenyje turèta baudžiamąsias bylas už nusikaltimus, užtraukiančius sunkiųjų darbų kalèjimo bausmę ir nepavestas kitiems teismams. Tuo tarpu Apeliaciniams rūmams pirmosios instancijos tvarka nagrinèti ịstatymas pavedè tik gana siaurą baudžiamųjų bylų kategoriją - Apeliaciniai rūmai pirmosios instancijos teismu buvo apygardos teismams neteismingoms baudžiamo- 
sioms byloms, t. y. dèl nusikalstamų darbų, padarytų „prieš valstybès saugumą“. Jos ir sudarè visas paminètas per tą laikotarpị pirmąja instancija nagrinètas 340 bylų.

Daugiausia tai buvo bylos už nusikalstamas veikas, kvalifikuotas pagal 1934 metų Tautai ir valstybei saugoti ịstatymo ${ }^{35}$, numačiusio nemaža ịvairių, kartais gerokai apibendrintai, nekonkrečiai suformuluotų nusikaltimų sudečių, tokių, kaip lietuvių tautos, Lietuvos valstybès, jos ženklo, vèliavos ir t. t. ǐžeidimas ar niekinimas, piliečių valstybinès ištikimybès, vieningumo ar atsparumo silpninimas, pramanytų ar iškraipytų žinių apie valstybės valdžios institucijos ar valstybès ịstaigos veikimą skleidimas, taip pat paramos nusikalstamam veikimui prieš Lietuvos valstybę užsienyje ieškojimas, priklausymas nesuderinamoms su Lietuvos valstybès ar lietuvių tautos interesu užsienio organizacijoms, maišto ar kitokio pavojingo valstybei nerimo kèlimas, agitavimas daryti tai, kas kenkia Lietuvos valstybės ar lietuvių tautos interesui ir kt. Iš tiesų, tarp Apeliacinių rūmų pirmąja instancija nagrinètų baudžiamųjų bylų buvo bylos dèl įvairiausių veikų, pradedant pramanytų gandų, sukeliančių „valstybei pavojingą nerimą“, skleidimu, nacionalistinių dainų, tuo „varant propagandą už nacionalistų idèjas“, dainavimu, „gerbtino ir brangintino, turinčio simbolinès reikšmès lietuvių tautai“ ąžuolo niekinimu, baigiant šnipinejjimu svetimai valstybei, priklausymu komunistų partijai, komunistiniu veikimu ir $\operatorname{pan}^{36}$.

İstatymams nepasisakius dèl galimybių skųsti šiose bylose Apeliacinių rūmų pirmosios instancijos tvarka padarytus sprendimus, Vyriausiojo Tribunolo visuotinis susirinkimas buvo prięjęs išvadą, jog Apeliacinių rūmų sprendimai bylose dèl nusikalstamų darbų valstybès saugumui galëjo būti skundžiami Vyriausiajam Tribunolui kasacijos tvarka ${ }^{37}$.

4. Bylos, oficialiai priskiriamos „kitų“ kategorijai, sudare gana ženklią Apeliacinių rūmų užbaigtų bylų dalị - per aptariamą laikotarpị tai 4446 bylos, arba beveik 44 procentai visų Apeliaciniuose rūmuose užbaigtų bylų. Šiuo požiūriu Apeliaciniai rūmai daugiausia buvo instancija nukentėjusiųjų skundams dèl prokurorų nutarimų apie kvotos arba tardymo nutraukimą (remiantis Lietuvoje galiojusiu carinès Rusijos baudžiamojo proceso ịstatymo 277 str.), taip pat dèl apygardos teismų nutarimų nutraukti baudžiamąji persekiojimą dèl nuostolių, padarytų neteisètais teisẻjų, prokurorų, kitų teismo valdininkų veiksmais, atlyginimo, tvarkomuosiuose posėdžiuose svarstyti ${ }^{38}$.

Apeliacinių rūmų pirmininkui Teismų santvarkos ịstatymas pavedè prižiūrèti apygardų teismus ir jų veiklą: lankyti teismus ir tikrinti jų darbą, išsireikalauti konkrečias bylas, reikalauti iš teisèjų žinių ir pasiaiškinimų, nurodyti teismams pašalinti pastebètą netvarką, siūlyti iškelti teisẻjams drausmines bylas. Ši priežiūra, kaip buvo 
akcentuota ịstatyme, negalejo liesti teisejjams garantuoto nepriklausomumo, jiems sprendžiant konkrečias bylas.

Tokiu būdu 1933 metų Teismų santvarkos įstatymas eilinei teismo bylai nustate trijų instancijų galimybę: dvi - t. y. pirmosios instancijos ir apeliacine tvarka - bylos sprendimui iš esmès, ir trečiąją, kasacinę - patikrinimui, ar teisingai ir nepažeidžiant byloje pritaikyti materialiniai ir procesiniai įstatymai. Beje, šis savo esme logiškas ir racionalus teismų sistemos patobulinimas visuotinio pritarimo nesusilaukè, ką rodo išeivijoje publikuota rekomendacija, atgavus Lietuvai nepriklausomybę, grị̌ti prie trijų grandžių teismų sistemos, buvusių Apeliacinių rūmų sąskaita praplečiant apygardos teismų kompetenciją, o juos pačius sujungiant su Vyriausiuoju Tribunolu ir sudarant vieną vyriausiąji teismą, siūlytą pavadinti Lietuvos Respublikos Teismu ${ }^{39}$.

\section{Apeliaciniai rūmai okupacijos sąlygomis}

1940-ieji nepriklausomos Lietuvos teismų sistemai reiškè užsitęsusio laikino likvidavimo pradžią.

Teismų sistemos griovimas bei naujos diegimas, prasidejus sovietinei Lietuvos okupacijai, nebuvo forsuojamas. Pradžioje tenkintasi skubiu „esminiu teismo organų personalinès sudèties pakeitimu“"40, „atleidžiant iš pareigų reakcinguosius teisèjus “41 ir ị jų vietą „paskiriant teisejjais asmenis iš darbininkų, valstiečių, pažangiosios darbo inteligentijos"42. Tam tikslui buvo skubiai pakoreguoti dar nepanaikinto 1933 metu Teismų santvarkos ịstatymo nuostatai, ịtvirtinę teisejjų nepakeičiamumo principą ir nustatę jiems aukštus kvalifikacinius reikalavimus: liepos $1 \mathrm{~d}$. paskelbtas tariamai laikinas šio įstatymo pakeitimas ${ }^{43}$, leidžiantis, motyvuojant „teisingumo darymo nauda", be kokių nors suvaržymų atleisti iš pareigų arba perkelti ị kitą vietą teisèjus be jų sutikimo ir formaliai laikinai, vieneriems metams, sankcionuojantis galimybę teisèjo pareigoms skirti bet kurị „pasiruošusị tam darbui“ asmenị, nekreipiant dèmesio i buvusios įstatymo redakcijos reikalaujamą mokslo cenzą, tarnybos stažą arba teisèjo egzaminų rezultatus; apie skiriamojo asmens pasirengimą teismo darbui pavesta laisvai spręsti teisingumo ministrui, tiksliau - jo vardu atitinkamoms partinėms instancijoms.

39 Kairys, J. Kai kurių teisinių problemų išvakarėse. Teisininkų žinios. 1954, 6: 5.

40 Bulavas, J. Lietuvos TSR teisingumo organizacija ir valdymas (1940-1967). Vilnius: Lietuvos TSR mokslų akademija, Ekonomikos institutas, 1968, p. 18.

41 Liakas, A. Tarybiniai teismai Lietuvoje 1940-1960 metais. Tarybu Lietuvos valstybes ir teisès dvidešimtmetis. Vilnius: Valstybinè politinès ir mokslinès literatūros leidykla, 1960, p. 213.

42 Apanavičius, M.; Dvareckas, S. Teismas ir teisingumas Lietuvos TSR. Vilnius: Mintis, 1984, p. 63.

43 Laikinas teismų santvarkos ịstatymo pakeitimas. Vyriausybès žinios. 1940, Nr. 713-5596. 
Patys pasiprašę, nuo liepos 5 d. pareigas Apeliaciniuose rūmuose nustojo èję E. Balbachas, S. Dorošukas ir M. Rašinskas; atleidus dar penkis, per keletą dienų juose teliko J. Gudauskis, iki rugsèjo 15 d. tebetituluotas teismo pirmininku, ir V. Šarka. Rūmų personalas buvo papildytas tarpukaryje keletą metų Mažeikiuose bei Kelmèje apylinkès teisèjo darbą dirbusiu L. Petrausku, keletui dienų nominaliai tapusiu naujuoju pirmininku, ir J. Zimanu - advokatu, nepriklausomybès metais nekart teismuose gynusiu komunistine veikla kaltinamus asmenis ${ }^{44}$.

Rugpjūtyje ịforminus Lietuvos ijungimą ì SSRS, jau imtasi diegti sovietinę teismų sistemą. Vietos buvusiems Lietuvos teismams nepaliko Lietuvai primestoji 1940 metų sovietinè konstitucija. Šios konstitucijos „priėmimo“ dieną vadinamasis liaudies seimas, jau pasivadinęs Lietuvos TSR Aukščiausiąja Taryba, oficialiai pritarè respublikos Aukščiausiojo teismo sudarymui, kurio nariu, tarp kitų, tapo naujasis Apeliacinių rūmų narys J. Zimanas ${ }^{45}$. Apeliaciniai rūmai (sykiu ir Vyriausiasis Tribunolas) oficialiai panaikinti nuo spalio $1 \mathrm{~d}^{46}$

Nemaža dalis buvusių teisèjų buvo represuoti, tarp jų i t atšiaurias Rusijos sritis ištremti buvę Apeliacinių rūmų teisèjai K. Kazlauskas, M. Mataitis, M. Rašinskas, S. Sasnauskas, S. Žilinskas ${ }^{47}$. Suimti L. Balbachas ir J. Gudauskis; pirmajam pavyko pasinaudoti repatriacijos i Vokietiją galimybe, antrasis buvo išlaisvintas prasidejus SSRS ir Vokietijos karui ir išsilaksčius kalejjimo administracijai ${ }^{48}$.

Bolševikus 1941 metais birželyje iš Lietuvos išvijus, Laikinoji Lietuvos vyriausybė deklaravo šalies nepriklausomybę. Prisièmusi ịstatymų leidžiamosios ir vykdomosios valstybès valdžių funkcijas, ji ėmėsi skubių priemonių teisminei valdžiai, kitaip tariant - iki sovietinės okupacijos veikusiai Lietuvos teismų sistemai, atkurti. Per radiją paskelbtu šios Vyriausybès teisingumo ministro M. Mackevičiaus birželio 29 d. ịsakymu buvusiems Lietuvos Respublikos teismų darbuotojams, dirbusiems iki 1940 m. birželio 15 d., nurodyta nedelsiant grị̌žti ị darbo vietas, perimti turètąsias patalpas, turtą, bylas ir jų administravimą; ten, kur teisèjų neliko ir nespèta paskirti naujų, laikinai administravimą pavesta perimti žemesniems tų ịstaigų tarnautojams, o tokių nesant, įstaigų apsaugą ịpareigota perimti policija ${ }^{49}$. I atsiradusias vakansijas

44 Vilbikas, A., supra note 5, p. 110.

45 Lietuvos liaudies seimas. Stenogramos ir medžiaga. Vilnius: Mintis, 1985, p. 211-212; Dèl LTSR Aukščiausiojo teismo veikimo laikinųjų nuostatų. Lietuvos TSR Aukščiausiosios Tarybos žinios. 1940, Nr. 1.

46 Dèl Vyriausiojo Tribunolo ir Apeliacinių rūmų panaikinimo. Lietuvos TSR Vyriausybès nutarimu ir potvarkiu rinkinys. 1940, Nr. 3.

47 L. K. Lietuvos teisininkų likimas. Teisininku žinios. 1954, 8: 2; 10: 4.

48 Ibid. Teisininkų žinios. 1954, 9: 4; Mūsų sukaktuvininkai. Teisininkų žinios. 1952, 1: 13; Baltūsis, S., supra note 26, p. 32.

49 Teisingumo ministro įsakymas Nr. 4. LCVA. F. R-1549, ap. 1, b. 28, lap. 45; Stravinskas, P. Lietuvos teismų teisinè padètis vokiečių okupacijos metu. Teisininkų žinios. 1954, 8: 3. 
imta skirti naujus žmones, pirmiausia pagal galimybes panaudojant žemesnio rango tų pačių ístaigų tarnautojus ${ }^{50}$.

Laikinai eiti Apeliacinių rūmų tvarkytojo pareigas teisingumo ministro liepos $1 \mathrm{~d}$. įsakymu pavesta buvusiam jų pirmininkui J. Gudauskiui ${ }^{51}$. Liepos 2 d. Laikinoji Vyriausybė paskelbè naikinanti sovietinès valdžios ịvestus ir atkurianti iki $1940 \mathrm{~m}$. birželio 15 d. galiojusius ịstatymus, tarp jų atnaujintas 1933 metų Teismų santvarkos istatymo veikimas. Remdamasis šiuo Vyriausybès nutarimu, teisingumo ministras liepos 4 d. J. Gudauskiui pavedė „atstatyti bolševikų valdžios sulikviduotuosius Apeliacinius rūmus ir pradèti darbą "52.

Tokiu būdu, okupacinei valdžiai nesikišant, sovietinius teismus Lietuvoje pakeitè atgaivinti iki sovietinès okupacijos veikę teismai ${ }^{53}$, atgavę „pilną jų nepriklausomybès metų vaizdą" "54. Grąžintas net teisèjų profesinès kvalifikacijos reikalavimas: liepos $15 \mathrm{~d}$. Teismų santvarkos įstatymo pakeitimu ${ }^{55}$ atkurta tvarka, leidžianti teisèjais skirti tik turinčius aukštąji teisinį išsilavinimą ir tinkamai pareigoms pasiruošusius asmenis ir tik išimtiniais atvejais - nebaigusius, bet teismuose dirbusius iki sovietinès okupacijos pradžios; uždrausta teisèjais skirti veikusius prieš lietuvių tautos interesus arba tiems interesams pavojingus žmones. Teisejjų skyrimas pavestas ministrui pirmininkui, teisingumo ministro teikimu.

Dèl šių Laikinosios Vyriausybės priemonių jau 1941 m. liepos 9 d. atsirado pagrindas konstatuoti, kad esantys panaikinti visi sovietų valdžios įsteigtieji teismai ir atkurti iki $1940 \mathrm{~m}$. birželio $15 \mathrm{~d}$. veikę teismai bei galioję ịstatymai ${ }^{56}$.

Nors Apeliaciniai rūmai, jų patalpoms esant užimtoms vokiečių kariuomenès, realiai veiklos kurị laiką negalèjo pradèti, o ejjusiam Rūmų pirmininko pareigas J. Gudauskiui teko glaustis Teisngumo ministerijos patalpose ${ }^{57}$, minètasis Laikinosios Vyriausybės liepos $2 \mathrm{~d}$. nutarimas kiek pakoregavo jų kompetenciją, be apeliacinès instancijos apygardos teismų išspręstoms baudžiamosioms byloms funkcijos, numatydamas dar ir pirmosios instancijos teismo ne tik politinio pobūdžio baudžiamosioms, bet ir kai kurioms civilinėms byloms funkciją.

Vokiečių okupacinei valdžiai 1941 m. rugpjūčio 5 d. Laikinąją Vyriausybę paleidus, lietuviški teismai, okupacinès valdžios vadinti krašto teismais, kiek tai buvo tuo

50 Braslauskas, J. Teismų kompetencijos nacių okupuotoje Lietuvoje klausimu. Jurisprudencija. 2001, 19 (11): 212.

51 Teisingumo ministro ịsakymas Nr. 9. LCVA. F. R-1549, ap. 1, b. 28, lap. 59.

52 Teisingumo ministro įsakymas Nr. 12. LCVA. F. R-1549, ap. 1, b. 28, lap. 77.

53 Teismų santvarkos įstatymo pakeitimas. Teisininkų kalendorius 1943 metams. Kaunas: LTD [be m.], p. 187; Baltūsis S., supra note 26, p. 31.

54 Stravinskas, P., supra note 49, p. 3.

55 Supra note 53.

56 Žinios apie Lietuvos teismus. LCVA. F. R-1549, ap. 1, b. 29, lap. 37.

57 Ibid. 
metu įmanoma, savo darbo nenutraukè. Formaliai susidarė ekstraordinarinè situacija, kai, įstatymų leidžiamąją ir vykdomąją valdžią Lietuvoje pasisavinus okupantams, ị okupacinị „teisingumą“ vykdančių institucijų rankas neperèjusi jos teisminė valdžia toliau vadovavosi lietuviškais ịstatymais ir savo sprendimus skelbé Lietuvos Respublikos vardu (vokiečiams vèliau tai uždraudus, jie imti skelbti ịstatymų vardu). Teismas šiuo atveju vadovavosi konstituciniu teisejjų nepriklausomumo principu, sudariusiu teisines prielaidas tęsti Lietuvos teisingumo valdžią, net ir esant sutrikdytoms kitoms valstybès valdžios funkcijoms ${ }^{58}$.

Okupanto interesams tenkinti - ne teisingumui vykdyti, o gyventojų pasipriešinimui slopinti ir okupanto vykdytam terorui legalizuoti - 1941 metu pabaigoje ísteigus Vokiečių aukštesnijjị teismą Rygoje ir ypač Vokiečių teismą Kaune (Deutsches Gericht Kauen) su skyriais Vilniuje ir Šiauliuose bei kai kuriuos kitus vokiečių teismus, jų veikla ženkliai susiaurino lietuviškų teismų, dabar teisingumą galejjusių vykdyti tiek, kiek tai nepriklausė vokiečių ịstaigų kompetencijaii ${ }^{59}$, galimybes ${ }^{60}$. Iš krašto teismų kompetencijos pašalintos civilinès bylos, „liečiančios vokiečių ir žydų tautybès asmenis, o taip pat klausimus, liečiančius žemès sklypus ir i̇mones“; baudžiamosiose bylose šie teismai liko kompetentingi tik teisiant ne vokiečių tautybès žmones, kurių nusikaltimai nebuvo susiję su vokiečių Reicho reikalais ir jei jiems gresianti bausmė buvo ne didesnè nei laisvės atėmimas iki šešerių metų. Vokiečių teismo prokuroro reikalavimu ir bet kurios kitos bylos turèjo būti perduotos vokiečių teismui ${ }^{61}$.

Jau funkcionuojančius Lietuvos teismus okupantai oficialiai sankcionavo („leido pradèti“ faktiškai jau daugiau nei pusmetį vykdomą jų veiklą) $1942 \mathrm{~m}$. vasario $14 \mathrm{~d}$. potvarkiu, nepalietusiu tik jau veikusio ir suspejjusio išspręsti „visą eilę bylų “62 $\mathrm{Vy}$ riausiojo Tribunolo, - buvo nurodyta, kad jis „savo darbo nepradeda“63. Tuo būdu Vyriausiasis Tribunolas okupacinès valdžios iš tiesų buvo panaikintas, dalị jo funkcijų perduodant Apeliaciniams rūmams kaip aukščiausiam likusiam krašto teismui ${ }^{64}$.

Teisejjų sudètimi ir kompetencija Apeliaciniai rūmai okupuotoje Lietuvoje jau mažai tepanašèjo ị nepriklausomybès laikų teismus ${ }^{65}$.

Pirmiausia, krašto teismai teisingumą galejo vykdyti tik tiek, kiek tai nepriklausẻ vokiečių ịstaigų kompetencijai. Apeliaciniuose rūmuose veikusiems Civiliniam ir

58 Stravinskas, P., supra note 49, p. 3.

59 Potvarkis dèl laikinojo krašto teisminių ịstaigų teisingumo darbo vykdymo Lietuvos generalinejje srityje. Teisininkų kalendorius 1943 metams. Kaunas: LTD [be m.], p. 193-194.

60 Stravinskas, P., supra note 49, p. 4.

61 Bulavas, J. Vokiškųu fašistu okupacinis Lietuvos valdymas. Vilnius: Lietuvos TSR mokslų akademija, Ekonomikos institutas, ,1969, p. 79.

62 Stravinskas, P., supra note 49, p. 4.

63 Supra note 59; Stravinskas, P., supra note 49, p. 4.

64 Baltūsis, S., supra note 26, p. 32.

65 Supra note 3, p. 12. 
Baudžiamajam skyriams pavesta spręsti apeliacinius ir kitokius skundus dèl apygardos teismo pirmąja instancija ngrinètų bylų sprendimų (antrosios instancijos nutarimai negalejo būti skundžiami). Buvusi Vyriausiojo Tribunolo kompetencija pavesta specialiai sudarytam Apeliacinių rūmų Ypatingajam skyriui, ị kurio sudètị ịejo Rūmų pirmininkas ir po du Civilinio bei Baudžiamojo skyrių narius, paskirtus Teisngumo generalinio tarejo. Be to, Ypatingasis skyrius buvo laikomas administraciniu teismu byloms, anksčiau spręstoms Vyriausiojo tribunolo ${ }^{66}$.

Isigaliojo reikalavimas skiriamus krašto teismų teisèjus teikti tvirtinti vokiečių generaliniam komisarui, kiekvienas jų privalejo įsipareigoti paklusti vokiečių civilinès valdžios potvarkiams ${ }^{67}$.

Apeliacinių rūmų pirmininku paskirtas S. Baltūsis. Civiliniame skyriuje, pirmininkaujamame J. Gudauskio, teisejjais dirbo J. Danauskas, J. Grigaitis ir J. Boreiša; Baudžiamajame, su J. Staškevičiumi priešakyje, teisèjavo P. Adomavičius, S. Dorošukas, P. Budrevičius, A. Augustauskas-Bredikis, V. Mieželis, V. Šarka, P. Duoba ir J. Valtys (pastarajam mirus - A. Valavičius) ${ }^{68}$. Iš keturiolikos paskutinių Apeliacinių rūmų teisèjų, dirbusių vokiečių okupacijos metais, penki juose buvo dirbę ir Lietuvai netenkant nepriklausomybės, septyni tuomet buvo Vyriausiojo Tribunolo, du - Kauno apygardos teismo teisèjais.

Lietuviškų krašto teismų, tarp jų ir Apeliacinių rūmų, veikla tęsėsi iki vokiečių okupacijos pabaigos: sovietinès kariuomenès užgrobtose teritorijose 1944 metų vasarą tiesiai imtasi atkurti sovietines teismo įstaigas, kuriomis susirūpinta dar 1942-1943 metais ir ėmus Sovietų sąjungos užfrontèje skubos tvarka rengti joms kadrus ${ }^{69}$. Formaliai sovietinių teismų veikla Lietuvoje atnaujinta 1944 m. sausio 25 d. Maskvoje sovietinės Lietuvos Liaudies komisarų tarybos nutarimu ${ }^{70}$.

Atgimimo Lietuvos teismų sistema tesulaukè po penkiasdešimties metų.

\section{Išvados}

1. Apeliacinių rūmų ịsteigimu 1933 metais užbaigtas Lietuvos Respublikos bendrosios kompetencijos teismų sistemos, išlikusios iki mūsų dienų, formavimas.

66 Antrasis parèdymas dèl laikinojo krašto teisminių įstaigų teisingumo darbo vykdymo Lietuvos generalineje srityje. Teisininkų kalendorius 1943 metams. Kaunas: LTD [be m.], p. 208.

67 Supra note 59, p. 194.

68 Apeliaciniai rūmai. Teisininku kalendorius 1943 metams. Kaunas: LTD [be m.], p. 119-120; Teisininku kalendorius 1944 metams. Kaunas: LTD [be m.], p. 120.

69 Apanavičius, M.; Dvareckas, S., supra note 42, p. 66; Liakas, A., supra note 41, p. 229.

70 Dèl Lietuvos TSR liaudies komisariatų ir centrinių ístaigų veiklos atnaujinimo ir jų aparato sukomplektavimo. Lietuvos TSR LKT $1944 \mathrm{~m}$. sausio 25 d. nutarimas Nr. 32. Lietuvos TSR ịstatymų, Aukščiausiosios Tarybos Prezidiumo ịsakų ir vyriausybès nutarimų chronologinis rinkinys. I tomas. Vilnius: Valstybinė politinès ir mokslinès lietartūros leidykla, 1956, p. 84. 
2. Pagrindinę Apeliaciniuose rūmuose baigtų bylų dalị tarpukaryje sudarè apeliacinès bylos, pirmąja instancija nagrinètos apygardos teismuose. Jos, taip pat pirmosios instancijos tvarka juose nagrinètos bylos už nusikaltimus valstybés saugumui, leidžia konstatuoti, kad ši teismo ịstaiga buvo skirta iš esmès baudžiamosioms byloms.

3. Oficialiai panaikinti sovietinès okupacijos pradžioje, Apeliaciniai rūmai kartu su kitais Lietuvos nepriklausomybès metų teismais atkurti prasidejjus vokiečių okupacijai. Okupantams perėmus ịstatymų leidžiamąją ir vykdomąją valdžią, lietuviška teisminè valdžia neperejo ị okupacinị „teisingumą“ vykdančių institucijų rankas.

\section{Literatūra}

Antrasis parèdymas dèl laikinojo krašto teisminių istaigų teisingumo darbo vykdymo Lietuvos generalinejje srityje. Teisininku kalendorius 1943 metams. Kaunas: LTD [be m.].

Apanavičius, M.; Dvareckas, S. Teismas ir teisingumas Lietuvos TSR. Vilnius: Mintis, 1984.

Apeliaciniai rūmai. Teisininkų kalendorius 1934 metams. Kaunas (be m.); Teisininku kalendorius 1943 metams. Kaunas: LTD [be m.]; Teisininku kalendorius 1944 metams. Kaunas: LTD [be m.].

Baltūsis, S. Lietuvos teismai. Sèja. 1974, $1 / 2$.

Baudžiamojo proceso ịstatymas (bendrieji dèsniai ir pirmoji knyga). „Teisès“ priedas A. Kriščiukaičio suredaguotas. Kaunas, 1924.

Byla, J. Lietuvos teismo dvidešimtmečio sukaktis. Teise. 1938, 44.

Byla, J. Teisimas nusik. darbų prieš valstybès saugumą. Teisé. 1935, 29.

Bylų eiga Apeliaciniuose rūmuose 1933 metais. Teisè. 1934, 25.

Bylų eiga Apeliaciniuose rūmuose 1935 metais. Teisè. 1936, 33.
Bylų eiga Apeliaciniuose rūmuose 1936 metais. Teise. 1937, 37.

Bylų eiga Apeliaciniuose rūmuose 1937 metais. Teisè. 1938, 41.

Bylų eiga Apeliaciniuose rūmuose 1938 metais. Teisé. 1939, 45.

Bylų eiga Apeliaciniuose rūmuose 1939 metais. Teisé. 1940, 50.

Braslauskas, J. Teismų kompetencijos nacių okupuotoje Lietuvoje klausimu. Jurisprudencija. 2001, 19 (11).

Bulavas, J. Lietuvos TSR teisingumo organizacija ir valdymas (1940-1967). Vilnius: Lietuvos TSR mokslų akademija, Ekonomikos institutas, 1968.

Bulavas, J. Vokiškujų fašistų okupacinis Lietuvos valdymas. Vilnius: Lietuvos TSR mokslų akademija, Ekonomikos institutas, 1969.

Dèl Lietuvos TSR liaudies komisariatų ir centrinių įstaigų veiklos atnaujinimo ir jų aparato sukomplektavimo. Lietuvos TSR LKT 1944 m. sausio 25 d. nutarimas Nr. 32. Lietuvos TSR įstatymu, Aukščiausiosios Tarybos Prezidiumo isaku ir Vyriausybes nutarimu chronologinis rinkinys. I tomas. Vilnius, 1956.

Dèl LTSR Aukščiausiojo Teismo veikimo laikinųjų nuostatų. Lietuvos TSR 
Aukščiausiosios Tarybos žinios. 1940, Nr. 1.

Dèl Vyriausiojo Tribunolo ir Apeliacinių rūmų panaikinimo. Lietuvos TSR Vyriausybès nutarimu ir potvarkių rinkinys. 1940, Nr. 3.

Kairys, J. Kai kurių teisinių problemų išvakarèse. Teisininkų žinios. 1954, 6.

Laikinasis Lietuvos teismų ir jų darbo sutvarkymas. Lietuvos Vyriausybes žinios. 1919, Nr. 2-3/26.

Laikinas Teismų santvarkos įstatymo pakeitimas. Vyriausybès žinios. 1940, Nr. 713-5596.

Laikinojo Lietuvos teismų ir jų darbo sutvarkymo, civilinio ir baudžiamojo proceso įstatymų pakeitimas ir papildymas. Vyriausybès žinios. 1921, Nr. $68 / 607$

Laikinojo Lietuvos teismų ir jų darbo sutvarkymo istatymo pakeitimas. $V y$ riausybès žinios. 1924, Nr. 160-1140; 1926, Nr. 238-1543.

LCVA. F. 932, apyrašas 1 - Apeliaciniai rūmai. Baudžiamosios bylos 1934-1940.

Liakas, A. Tarybiniai teismai Lietuvoje 1940-1960 metais. Tarybu Lietuvos valstybès ir teisès dvidešimtmetis. Vilnius: Valstybinè politinès ir mokslinès literatūros leidykla, 1960.

Lietuvos apeliacinis teismas. The Court of Appeal of Lithuania [be v. ir d.].

Lietuvos liaudies seimas. Stenogramos ir medžiaga. Vilnius: Mintis, 1985.

Lietuvos teismas 1918-1928. Red. A. Kriščiukaitis. Kaunas: Teisingumo ministerija, 1930, p. 202.

Lietuvos Valstybes Tarybos protokolai 1917-1918. Sudarè A. Eidintas ir R. Lopata. Vilnius: Mokslas, 1991.

L. K. Lietuvos teisininkų likimas. Teisininkų žinios. 1954, 8; 9; 10.
Mačys, V. Teisingumo ministerijos 1921 metų darbuotès apžvalga. Teisè. 1922, 2.

Maksimaitis, M. Teismų santvarkos pagrindų formavimasis Lietuvoje (1918-1933). Jurisprudencija. 2013, 20 (2).

Ministrų kabineto 19280807 pos. protokolas. LCVA. F. 923, ap. 1, b. 556.

Mūsų sukaktuvininkai. Teisininkų žinios. 1952, 1.

Oficialinè dalis. Teisè. 1933, 24; 1940, 50.

Paaiškinamasis raštas prie Teismų sutvarkymo įstatymo projekto. LCVA. F. 1556, ap. 3, b. 16.

Paaiškinimas įstatymui „Laikinasis Lietuvos teismų ir jų darbo sutvarkymas“. Lietuvos Vyriausybès žinios. 1919, Nr. 2-3/27.

Potvarkis dèl laikinojo krašto teisminių ìstaigu teisingumo darbo vykdymo Lietuvos generalinèje srityje. Teisininku kalendorius 1943 metams. Kaunas: LTD [be m.].

Respublikos Prezidento aktai. Vyriausybès žinios. 1939, Nr. 675-4992, 4994, 4995, Nr. 679-5033.

Römeris, M. Administracinis teismas. Kaunas: Lietuvos universitetas, Teisių fakultetas, 1928.

Römeris, M. Konstitucines ir teismo teises pasieniuose. Kaunas: Vytauto Didžiojo universiteto Teisių fakultetas, 1931.

Römeris, M. Teisinès valstybės organizacija. Lietuvos universitetas 1927-1928 mokslo metais (1927.IX.1 -1928.II.16). Kaunas: Lietuvos universitetas, 1928.

Sagatienè, D. Sovietiniai bendrosios kompetencijos teismai Lietuvoje 1940-1941 ir 1944-1953 metais. Daktaro disertacija. Socialiniai mokslai, teisè. Vilnius: Mykolo Romerio universitetas, 2013.

Sąmajauskas, K. Lietuviškasis teismas. Teisè. 1934, 25. 
Skipitis, R. Petras Leonas - Lietuvos teisingumo kūrèjas. Teisininkų žinios. $1965,27 / 28$.

Stravinskas, P. Lietuvos teismų teisinè padètis vokiečių okupacijos metu. Teisininkų žinios. 1954, 8.

Tautai ir valstybei saugoti įstatymas. $V y$ riausybès žinios. 1934, Nr. 437-3044.

Teisingumo ministerijos etatų pakeitimas. Vyriausybès žinios. 1933, Nr. 422-2917; 1934, Nr. 437-3046; 1939, Nr. 631-4525.

Teisingumo ministro įsakymas Nr. 4, Nr. 9, Nr. 12. LCVA. F. R-1549, ap. 1, b. 28 .

Teismų santvarkos įstatymas. Vyriausybes žinios. 1933, Nr. 419-2900.
Teismų santvarkos įstatymo pakeitimas. Vyriausybès žinios. 1939, Nr. 6314531.

Teismų santvarkos įstatymo pakeitimas. Teisininku kalendorius 1943 metams. Kaunas: LTD [be m.].

Teismų sutvarkymo įstatymas. Projektas. LCVA. F. 1556, ap. 3, b. 16.

Toliušis, Z. Lietuvos teismų sutvarkymas. Antroji laida. Kaunas, 1926.

Vilbikas, A. Teismai ir teisejjai Lietuvoje (1918-2008). Šiauliai, 2009.

Vilniaus universiteto istorija 1803-1940. Vilnius: Mokslas, 1977.

Žinios apie Lietuvos teismus. LCVA. F. R-1549, ap. 1, b. 29.

Anotacija. Straipsnis skiriamas 1933 m. rugsejo 15 d. Teismų santvarkos įstatymu isteigtai naujai tos sistemos grandžiai - Apeliaciniams rūmams, užbaigusiai Lietuvos Respublikos bendrosios kompetencijos teismu sistemos, iš esmés tebefunkcionuojančios iki mūsų dienų, formavimą. Siekiama atskleisti šios teisminès institucijos isteigimo tikslus ir eiga, jos organizacijos ir veiklos pagrindus bei reikšmę ir likima okupaciju. metais.

Reikšminiai žodžiai: teismy santvarka, teismų istorija, Lietuvos teismai, Apeliaciniai rūmai.

\title{
FROM THE HISTORY OF LITHUANIAN COURTS: THE COURT OF APPEAL (1933-1944)
}

\author{
Mindaugas Maksimaitis \\ Mykolas Romeris University, Lithuania
}

Summary. A temporary law of Courts of Lithuania and their work order promulgated in 1918 determined the three level court system with no cassation, where the decisions of the appeal as the higher court level were considered as final. Subsequently, in 1921, the partial cassation was instituted that concerned the cases solved by the Justices of the Peace and processed at the stage of appeal by district courts. Afterwards, it took almost the decade to prepare the bill supplementing the court system 
with the special court of cassation and revision. The law was adopted and came into force in 1933.

The Chief Tribunal from the highest level of court system was reorganized into the Court of Cassation. The court system was also supplemented by the new Republic-wide court of appeal called the Court of Appeal. The aforementioned court was proclaimed as the first instance court assigned to deal with slender criminal cases concerning criminal behavior directed to security of the State, however, the main field of its duty became investigation of cases at the stage of appeal that were tried by the first instance courts.

After submitting by law all the civil cases to district courts, at the stage of appeal the cases had to be investigated in higher level district courts. Yet the Court of Appeal became an appeal instance for civil cases that according to the previous procedure were tried in the first instance by the higher level district courts. The unfinished aforementioned cases were left to be dealt with by the Court of Appeal.

Right after the occupation of the Soviet Union, the Court of Appeal together with other courts of the year of independence were abolished and by the new-formed temporary Government were reconstituted right after the German occupation. After the legislative and executive power was taken over by the recent occupants, the Lithuanian judiciary did not turn into the institution executing the occupation justice. According to the interest of invaders in the territory of Lithuania, the separate German judiciary system was formed and functioned in parallel with the Lithuanian judiciary system.

Keywords: judicial system, the history of the courts, the courts of Lithuania, the Court of Appeal.

Mindaugas Maksimaitis, Mykolo Romerio universiteto Teisès fakulteto Teisès filosofijos ir istorijos katedros profesorius emeritas. Mokslinių tyrimų kryptis: Lietuvos teisès ir teisinès minties istorija.

Mindaugas Maksimaitis, Mykolas Romeris University, Faculty of Law, Departament of Philosophy and History of Law, Professor Emeritus. Research interests: history of Lithuanian law and legal thought. 